De Weerdt, J., Patulny, C., \& Clapham, P. (2021). The yellowbellied sea snake, Hydrophis platurus (Squamata: Elapidae), off the Southwestern Pacific coast of Nicaragua, Central America. Revista de Biología Tropical, 69(Suppl. 2), S297-S303. https://doi.org/10.15517/rbt.v69iS2.48324

\title{
The yellow-bellied sea snake, Hydrophis platurus (Squamata: Elapidae), off the Southwestern Pacific coast of Nicaragua, Central America
}

\author{
Joëlle De Weerdt ${ }^{1,2}$; (D) https://orcid.org/0000-0003-4054-6609 \\ Carla Patulny ${ }^{1}$; (D) https://orcid.org/0000-0001-7232-3341 \\ Phillip Clapham³; (D https://orcid.org/0000-0002-2776-5746 \\ 1. Association ELI-S, 39 Allée de Verdalle, 33470 Gujan-Mestras, France; eliscientific@gmail.com \\ 2. Vrije Universiteit Brussel, Pleinlaan 2, 1050 Brussel, Belgium \\ 3. Seastar Scientific, 27605 Hake Road SW, Vashon WA 98070, USA; phillip.clapham@gmail.com
}

Received 12-XI-2020. C Corrected 30-I-2021. Accepted 28-II-2021.

\begin{abstract}
Introduction: The yellow-bellied sea snake (Hydrophis platurus, formerly Pelamis platurus) is known to occur along the Pacific coast of Central America. However, there are no marine records of this species off the coast of Nicaragua.

Objective: Report the first in situ marine observations of the yellow-bellied sea snake observed on three occasions in 2020 during cetacean surveys off the southwestern Pacific coast of Nicaragua.

Methods: During the sightings, photographs were taken which allowed the identification of the species based on morphology. Sea surface temperature, sea state, and distance to the coast are presented as descriptors of the habitat of the records.

Results: Three field observations of yellow-bellied sea snakes were recorded on separate occasions. Sightings occurred within $30 \mathrm{~km}$ of each other and $3.3 \mathrm{~km}$ from the coast. Average sea surface temperature was $26.6{ }^{\circ} \mathrm{C}$ with low swell and sea state.

Conclusions: The present information offers new knowledge about the presence of the yellow-bellied sea snake on the Pacific coast of Central America, contributing to the biodiversity record in Nicaragua.
\end{abstract}

Key words: Pelamis platurus; sea snakes; reptiles; Eastern Tropical Pacific; San Juan del Sur; distribution.

Marine reptiles such as sea snakes play an important trophic role in marine ecosystems (Brischoux \& Lillywhite, 2013; Voris, 1972) and their distribution encompasses mainly tropical waters (Tu, 1988). The yellow-bellied sea snake, Hydrophis platurus (previously: Pelamis platurus), is the most widely distributed hydrophiid snake in the world (Hernández-Camacho et al., 2005; Lomonte et al., 2014; Quiñones et al., 2014) and is the only pelagic species (Brischoux \& Lillywhite, 2011;
Heatwole, 1999; Sheehy et al., 2012). The presence of this species has been confirmed in the Eastern Tropical Pacific, from the coasts of Mexico to northern Peru (Brischoux \& Lillywhite, 2011; Graham, Rubinoff, \& Hecht, 1971; Quiñones et al., 2014).

The movement patterns of $H$. platurus remain largely unknown. Marine currents (Kropach, 1971) and sea surface temperature (SST) (Quiñones et al., 2014) are environmental parameters related to their distribution patterns, 
with ocean currents playing an important role in the the movement of $H$. platurus (Brichoux et al., 2016). Slicks are formed when surface currents converge and snakes passively drift within these slicks (Kropach, 1971). The abundance of snakes on a slick can be influenced by the quantity of flotsam found within the slick (Brischoux \& Lillywhite, 2011). The yellow-bellied sea snake is a 'passive surface drifter' and is often transported by currents to locations where it is not considered resident (Dunson \& Ehlert, 1971).

As an ectotherm, sea surface temperature (SST) limits the species' distribution to a minimum of $18{ }^{\circ} \mathrm{C}$, since locomotor abilities and feeding are inhibited or cease at lower SSTs (Heatwole, Grech, Monahan, King, \& Marsh, 2012); and to a maximum of $33{ }^{\circ} \mathrm{C}$ (Dunson $\&$ Ehlert, 1971). These SST ranges prevent the species from colonising regions such as the Atlantic Ocean ( Lillywhite et al., 2018; Quiñones et al., 2014) and the Pacific coast of South America, where strong upwelling of cold water limits their distribution (Dunson \& Ehlert, 1971). Waters off Central America represent optimal thermal conditions for the yellowbellied sea snake, since mean monthly temperatures of $>25{ }^{\circ} \mathrm{C}$ are the minimum required for feeding (Hecht, Kropach, \& Hecht, 1974). Although $H$. platurus has a natural preference for offshore waters, the species has been also recorded in shallow coastal waters (Heatwole, 1999; Hecht et al., 1974). Its dependence on freshwater to avoid water deficits due to dehydration during dry season may explain their coastal distribution in Costa Rica (Lillywhite et al., 2010), but its still controversed (Lillywhite et al., 2014; Lillywhite et al., 2019).

Daylight is a determining factor in the surfacing behavior of $H$. platurus; it shows a preference for high light levels (Brischoux \& Lillywhite, 2011) and is not often observed at the sea surface at night (Brischoux \& Lillywhite, 2011); however the latter needs further investigation due to a lack of samples. In Central America, H. platurus has been reported in the Gulf of Fonseca, Honduras (McCranie \& Gutsche, 2016; Solis et al., 2014), the Pacific coast of Costa Rica (Bolaños et al., 1974; Tu,
1976; Tu \& Salafranca, 1974), the Pacific coast of El Salvador (Hidalgo, 1980) and the Gulf of Panama (Guinea et al., 2017; Kropach, 1971; Vallarino \& Weldon, 1996). Yellow-bellied sea snakes have been frequently reported in the Pacific coast of Nicaragua between the Gulf of Fonseca (Chinandega) and San Juan del Sur (Rivas) (HerpetoNica, 2015), however, observations are limited to beach strandings and no data is available on the marine occurrence of this species. To date, no marine records have been published on the presence of the yellowbellied sea snake in Nicaragua. Here, we report, for the first time, the presence of H. platurus in the southwestern Pacific waters of Nicaragua, offering additional insights into distribution and behavioral patterns of this marine snake in the Eastern Tropical Pacific.

\section{MATERIALS AND METHODS}

Data were gathered during systematic boat-based surveys from January to midMarch 2020. Surveys were conducted using a $6 \mathrm{~m}$ length fiberglass boat, between 0800 and $1700 \mathrm{~h}$ daily. When the yellow-bellied sea snake was found, the following data were collected: date, time, Global Positioning System location, sea surface temperature (SST, Hecht thermometer), sea state (using the Beaufort scale), and swell categorized as either Low (L), less than one meter; Medium (M) 1-2 m; and High $(\mathrm{H})$ more than two meters (Table 1). Photographs were taken using a DSLR camera with a 55-300 mm lens, and were used for specimen identification based upon standard morphological characteristics (see below). Maps indicating sighting locations were generated with ArcGIS. Distance from the nearest point on the coast was measured for each sighting location using the line tool in ArcGIS.

\section{RESULTS}

Three field observations of yellow-bellied sea snakes were made on 28 and 29 January 2020 (photographed) and 04 March 2020 (photographed) (Fig. 1). Based on photographic 


\section{TABLE 1}

Overview of field records of the yellow-bellied sea snake (Hydrophis platurus) off the South-West Pacific coast of Nicaragua, including sighting date and time, latitude and longitude, SST, Beaufort scale and swell, and distance from the coast

\begin{tabular}{cccccccccc}
\hline Date & Time & Latitude & Longitude & $\begin{array}{c}\text { SST } \\
\left({ }^{\circ} \mathrm{C}\right)\end{array}$ & Picture & Sex & Beaufort & $\begin{array}{c}\text { Swell } \\
\text { Distance from } \\
\text { coast }(\mathrm{km})\end{array}$ \\
\hline 28 Jan 2020 & $12: 04$ & $11^{\circ} 7^{\prime} 21.698^{\prime \prime} \mathrm{N}$ & $85^{\circ} 50^{\prime} 29.198^{\prime \prime} \mathrm{W}$ & 27 & No & Uk & 1 & $\mathrm{~L}$ & 4.6 \\
29 Jan 2020 & $16: 24$ & $11^{\circ} 18^{\prime} 39.802^{\prime \prime} \mathrm{N}$ & $85^{\circ} 58^{\prime} 54.199^{\prime} \mathrm{W}$ & 28 & Fig. 1a & Uk & 1 & L & 3.8 \\
04 Mar 2020 & $16: 05$ & $11^{\circ} 20^{\prime} 30.699^{\prime} \mathrm{N}$ & $85^{\circ} 00^{\prime} 27.698^{\prime} \mathrm{W}$ & 25 & Fig. 1b & Uk & 4 & L & 1.4 \\
\hline
\end{tabular}

SST $=$ Sea Surface Temperature, Uk = unknown.

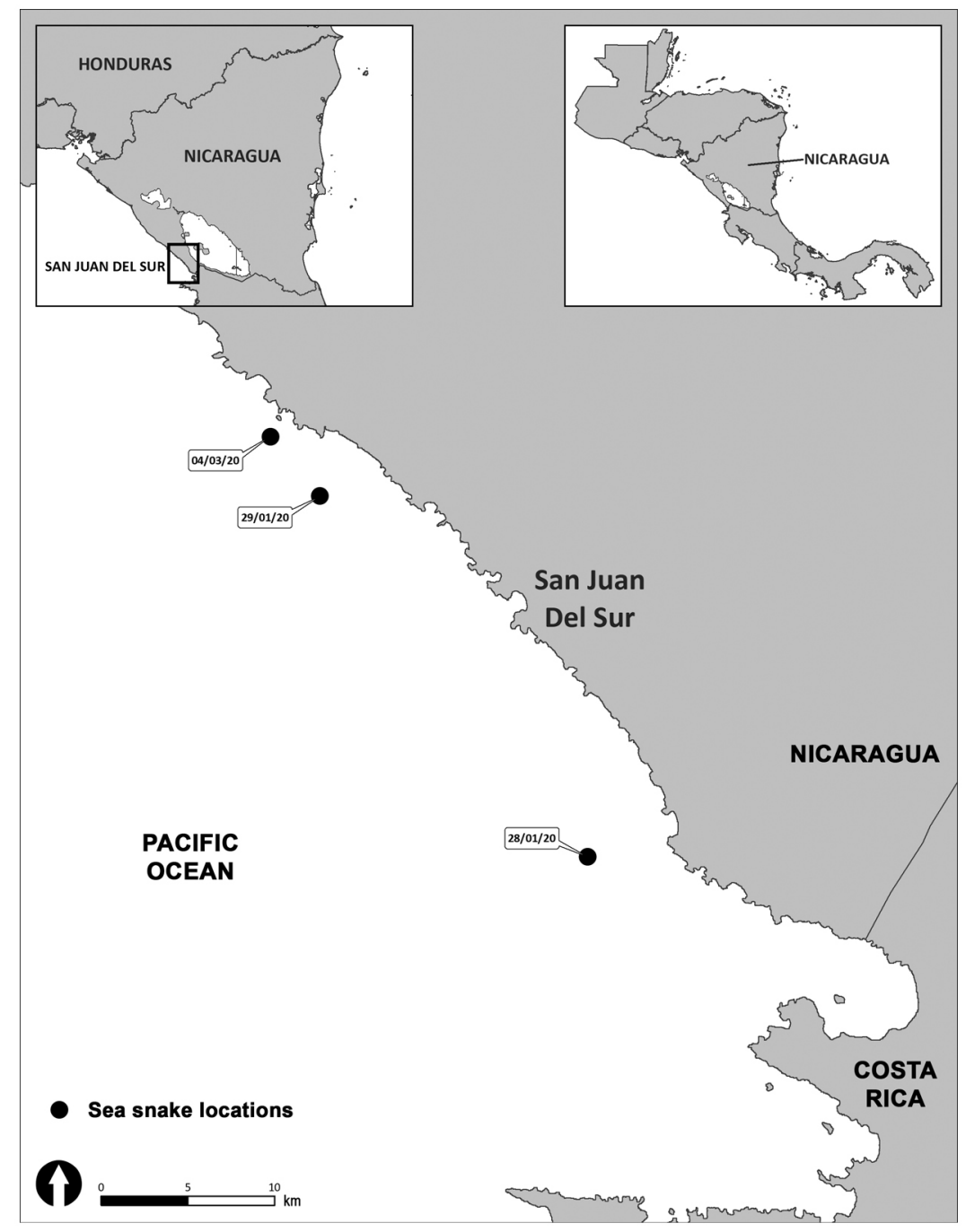

Fig. 1. Location of the yellow-bellied sea snake (Hydrophis platurus) observations with reference to the date of observation, south Pacific of Nicaragua. 


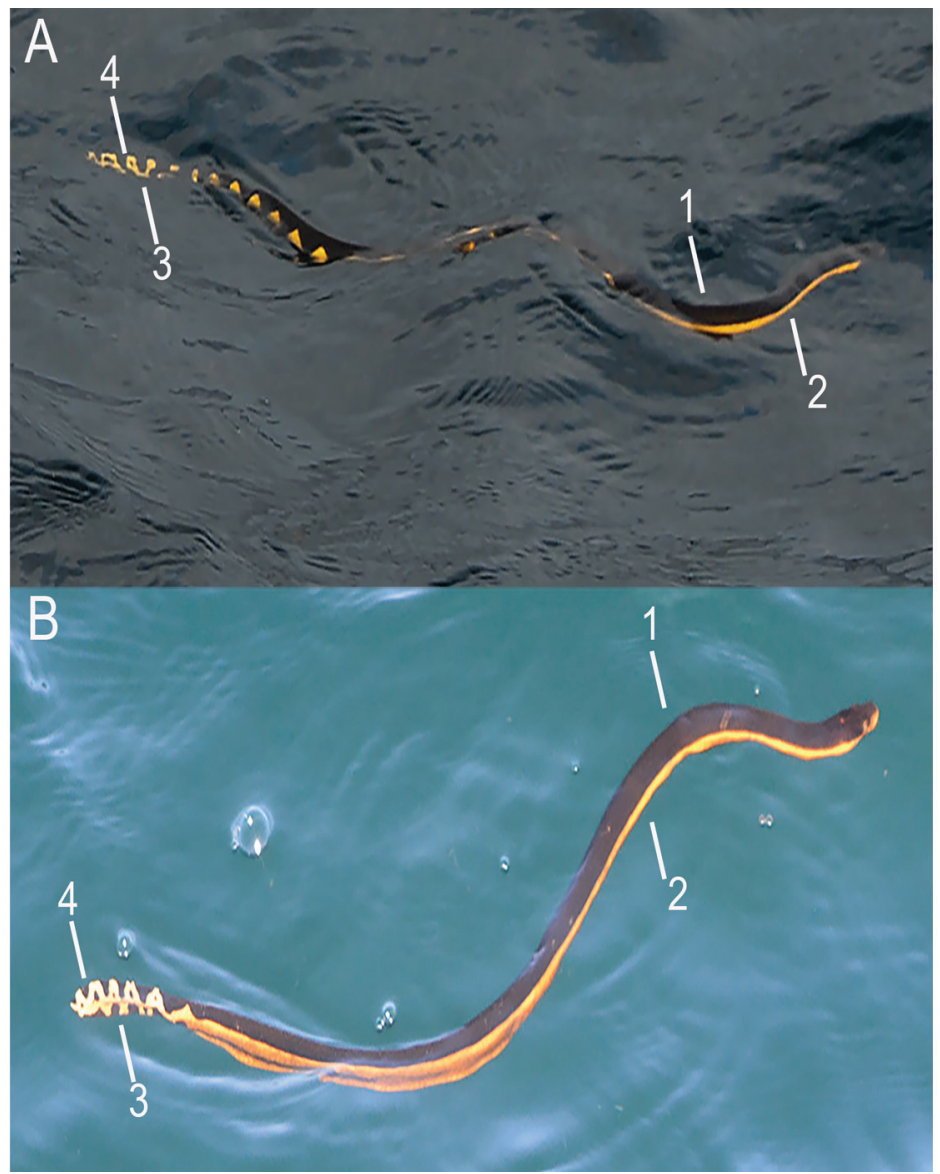

Fig. 2. Morphological features for identification of the yellow-bellied sea snake include: 1) Black dorsal side 2) yellow ventral side 3) Dark tail spots 4) Paddle-shaped tail. A) Individual photographed on 29 January 2020 with a partially straight dorsal band; B) Individual photographed on 04 March 2020 with a straight dorsal band with the exception of subcaudal portion. Color pattern as described by Tu (1976).

observations, the following morphological features confirmed the identification of the species: 1) Black dorsal side extending from the head to the tail with variations in the dorsal band pattern; 2) Yellow ventral side extending from the head to the tail; 3) Dark spots on the tail; 4) Paddle-shaped tail. Both photographed individuals were bi-colored and displayed two distinct color patterns (Fig. 2). Sex and size could not be inferred or measured from the photographs. On the three occasions, the yellow-bellied sea snake was swimming alone at the surface and moved southwards. Each individual dived after traveling at the surface for a few minutes. Sightings occurred in a range of $30 \mathrm{~km}$ from each other and $3.3 \mathrm{~km}$ from the coast. The average SST was $26.6{ }^{\circ} \mathrm{C}$ $( \pm 1.25 \mathrm{SD}, \mathrm{N}=3$ ) (Table 1). Swell was low on all occasions and the Beaufort sea state ranged between 1 and 4 (Table 1).

\section{DISCUSSION}

Our observations confirm the presence of yellow-bellied sea snakes in shallow coastal waters off the southwestern coast of Nicaragua. Extensive variation in color patterns of this species has been documented, with almost completely black and entirely yellow specimens represented at each end of the spectrum 
(Solórzano, 2011). In addition, the patterns of the black dorsal band vary from straight to completely curved, and spots may be completely absent (Tu, 1976). All three of our sighted individuals were bi-colored, as also observed in other Central American regions (Hidalgo, 1980; Tu, 1976).

The bi-color pattern is commonly observed in juvenile yellow-bellied sea snakes, which develop the tri-color pattern during ontogeny (Tu \& Salafranca, 1974). The observation made on the 28 January 2020 (Fig. 2A) displayed a saw-edged dorsal band which matches specimens found in El Salvador and Costa Rica (Hidalgo, 1980; Tu, 1976), while the observation made on the 04 March 2020 (Fig. 2B) did not display the dorsal pattern which is consistent with juvenile descriptions of specimens found in Costa Rica (Tu, 1976).

The mean measured SST of $26.6^{\circ} \mathrm{C}$ falls within the range of optimal feeding temperatures (Hecht et al., 1974). Although our observations of solitary snakes were made in such conditions, the snakes were probably not involved in feeding behaviors, due to the absence of slicks with which they tend to associate for feeding (Dunson \& Ehlert, 1971; Kropach, 1971). The observation of solitary snakes not associated with slicks is commonly observed in Panama (Kropach, 1971) and Costa Rica (Brischoux \& Lillywhite, 2011).

Our sightings of yellow-bellied sea snakes occurred within $5 \mathrm{~km}$ of the coast which coincides with other records in neighboring countries (Solòrzano, 2004; Tu, 1976). The underlying factors for the coastal occurrence of this offshore species remains largely unclear, even if it was suggested that their reliance on freshwater could be responsible for the coastal distribution (Lillywhite et al., 2010) recent studies did not support this hypothesis (Lillywhite, 2019). All our field observations were made in the afternoon, which contrasts with findings in the Papagayo Gulf, Costa Rica, where snakes were not observed in the afternoon (Tu, 1976).

Even though yellow-bellied sea snakes are frequently reported on the beaches of
San Juan del Sur and surrounds, no previous report on their marine distribution has been made. The present paper presents, to the best of our knowledge, the first marine report of this species in the Pacific waters of Nicaragua. The presence of non-feeding, lone, bi-colored individuals in coastal areas can help researchers understand the ecology and movement patterns of the species off Central America in the Eastern Tropical Pacific. Additional research is needed to understand the correlation between environmental parameters, such as oceanic currents, and the distribution patterns of the yellow-bellied sea snake in Nicaragua.

Ethical statement: authors declare that they all agree with this publication and made significant contributions; that there is no conflict of interest of any kind; and that we followed all pertinent ethical and legal procedures and requirements. All financial sources are fully and clearly stated in the acknowledgements section. A signed document has been filed in the journal archives.

\section{ACKNOWLEDGMENTS}

Special thanks to the research team that helped us gather information in the field: Sylvain Porrot, Audrey Mazza, Theresa Schabacker, Maëline Caradec, Galanne Cestre, Flordespina Dodds, Pierre Vachaudez, Aurèle de Thibault, and to Brock Boven for the production of the map.

\section{RESUMEN}

\section{Observaciones de la serpiente marina Hydrophis platurus (Squamata: Elapidae) en el Pacífico sur de Nicaragua, América Central}

Introducción: La serpiente marina de vientre amarillo (Hydrophis platurus, anteriormente Pelamis platurus) se encuentra distribuida a lo largo de la costa del Pacífico de América Central. Sin embargo, no existe registros in situ sobre esta especie en la costa del Pacífico de Nicaragua. Objetivo: Reportar las primeras observaciones in situ de la serpiente marina de vientre amarillo en tres ocasiones durante el 2020 frente a la costa suroeste del Pacífico de Nicaragua. 
Métodos: Los registros se realizaron de manera oportunista durante avistamientos de cetáceos en la zona. Las serpientes marinas fueron fotografiadas para su identificación a nivel de especie en base a su morfología. Durante cada avistamiento se registró la temperatura de la superficie del mar, el estado del mar y la distancia a la costa como descriptores del hábitat.

Resultados: Se registraron tres serpientes marinas de vientre amarillo en distintas ocasiones. Los avistamientos ocurrieron a menos de $30 \mathrm{~km}$ entre sí y a $3.3 \mathrm{~km}$ de la costa. La temperatura media de la superficie del mar fue de $26.6^{\circ}$ $\mathrm{C}$ con oleaje y estado de la mar bajos.

Conclusiones: El presente estudio brinda nuevo conocimiento sobre la distribución de la serpiente de vientre amarillo en la costa del Pacífico de Centroamérica, contribuyendo al registro de biodiversidad en Nicaragua.

Palabras clave: Pelamis platurus; serpientes marinas; reptiles; Pacífico Tropical Oriental; San Juan del Sur; distribución.

\section{REFERENCES}

Bolaños, R., Flores, A., Taylor, R. T., \& Cerdas, L. (1974). Color patterns and venom characteristics in Pelamis platurus. Copeia, 1974(4), 909-912. https://doi. org/10.2307/1442589

Brischoux, F., Cotté, C., Lillyhwhite, H. B., Lalire, M., \& Gasper, P. (2016). Oceanic circulation models help to predict global biogeography of pelagic yellow-bellied sea snake. Biology Letters, 12(8), 20160436. https:// doi.org/10.1098/rsbl2016.0436

Brischoux, F., \& Lillywhite, H. B. (2011). Light- and flotsam-dependent 'float-and-wait' foraging by pelagic sea snakes (Pelamis platurus). Marine Biology, 158(10), 2343-2347. https://doi.org/10.1007/ s00227-011-1738-Z

Brischoux, F., \& Lillywhite, H. B. (2013). Trophic consequences of pelagic life-style in yellow-bellied sea snakes Marine Ecology Progress Series, 478, 231-238.

Dunson, W. A., \& Ehlert, G. W. (1971). Effects of temperature, salinity, and surface water flow on distribution of the sea snake Pelamis. Limnology and Oceanography, 16(6), 845-853. https://doi.org/10.4319/ lo.1971.16.6.0845

Graham, J. B., Rubinoff, I., \& Hecht, M. K. (1971). Temperature physiology of the sea snake Pelamis platurus: An index of its colonization potential in the Atlantic Ocean. Proceedings of the National Academy of Sciences, 68(6), 1360-1363. https://doi.org/10.1073/ pnas.68.6.1360

Guinea, M., Lukoschek, V., Cogger, H., Rasmussen, A., Murphy, J., Lane, A., . . Karns, D. (2017). Hydrophis platurus. The IUCN red list of thretened species 2017. https://dx.doi.org/10.2305/IUCN.UK.20172RLTS.T176738A115883818.en.

Heatwole, H. (1999). Sea Snakes (2nd ed.). Sydney, Australia: University of New South Wales Press.

Heatwole, H., Grech, A., Monahan, J. F., King, S., \& Marsh, H. (2012). Thermal biology of sea snakes and sea kraits. Integrative and Comparative Biology, 52(2), 257-273. https://doi.org/10.1093/icb/ics080

Hecht, M. K., Kropach, C., \& Hecht, B. M. (1974). Distribution of the yellow-bellied sea snake, Pelamis platurus, and its significance in relation to the fossil record. Herpetologica, 30(4), 387-396.

Hernández-Camacho, J. I., Alvarez-León, R., \& RenjifoRey, J. M. (2005). Pelagic sea snake Pelamis platurus (Linnaeus, 1766) (Reptilia: Serpentes: Hydrophiidae) is found on the Caribbean Coast of Columbia. Memoria de la Fundación La Salle de Ciencias Naturales, 164, 143-152.

Hidalgo, H. (1980). Occurance of Pelamis platurus (Linnaeus) in El Salvador. Herpetological Review, 11(4), 117.

Kropach, C. (1971). Sea snake (Pelamis platurus) aggregations on slicks in Panama. Herpetologica, 27(2), 131-135.

Lillywhite, H. B., Sheehy III, C. M., Brischoux, F., \& Grech, A. (2014). Pelagic sea snakes dehydrate at sea. Proceedings of the Royal Society B: Biological Sciences, 281(1782), 20140119. https://doi.org/10.1098/ rspb.2014.0119

Lillywhite, H. B., Sheehy III, C. M., Heatwole, H., Brischoux, F., \& Steadman, D. W. (2018). Why are there no Sea Snakes in the Atlantic? Bioscience, 68(1), 15-24. https://doi.org/10.1093/boisci/bix132

Lillywhite, H. B., Sheehy III, C. M., Sandfoss, M. R., Crowe-Riddell, J., \& Grech, A. (2019). Drinking by sea snakes from oceanic freshwater lenses at first rainfall ending seasonal drought. PLOS ONE, 14(2), e0212099. https://doi.org/10.1371/journal. pone.0212099

Lillywhite, H. B., Solórzano, A., Sheehy III, C. M., Ingley, S., \& Sasa, M. (2010). New perspectives on the ecology and natural history of the yellow-bellied sea snake (Pelamis platurus) in Costa Rica: Does precipitation influence distribution? IRCF Reptiles \& Amphibians, 17(2), 69-72.

Lomonte, B., Pla, D., Sasa, M., Tsai, W., Solórzano, A., Ureña-Díaz, J. M., . . . Calvete, J. J. (2014). Two color morphs of the pelagic yellow-bellied sea snake, Pelamis platura, from different locations of Costa Rica: Snake venomics, toxicity, and neutralization by antivenom. Journal of Proteomics, 103, 137-152. https://doi.org/10.1016/j.jprot.2014.03.034 
HerpetoNica. (2015). Guía ilustrada de los anfibios y reptiles de Nicaragua. Managua, Nicaragua: Grupo Herpetológico de Nicaragua, MARENA.

McCranie, J. R., \& Gutsche, A. (2016). The herpetofauna of islands in the Golfo de Fonseca and adjacent waters, Honduras. Mesoamerican Herpetology, 3(4), 841-899.

Quiñones, J., Garćia Burneo, K., \& Barragan, C. (2014). Rediscovery of the yellow-bellied sea snake, Hydrophis platurus (Linnaeus, 1766) in Máncora, northern Perú. Check List, 10(6), 1563-1564.

Sheehy III, C. M., Solórzano, A., Pfaller, J. B., \& Lillywhite, H. B. (2012). Preliminary insights into the phylogeography of the yellow-bellied sea snake, Pelamis platurus. Integrative and Comparative Biology, 52(2), 321-330. https://doi.org/10.1093/icb/ics088

Solis, J. M., Wilson, L. D., \& Townsend, J. H. (2014) An updated list of the amphibians and reptiles of Hondurus, with comments on their nomenclature. Mesoamerican Herpetology, 1(1), 122-144.

Solórzano, A. (2004). Serpientes de Costa Rica : distribución, taxonomİa e historia natural. Santo Domingo de Heredia, Costa Rica: INBio.

Solórzano, A. (2011). Variación de color de la serpiente marina Pelamis platura (Sepentes: Elapidae) en el
Golfo Dulce, Puntarenas, Costa Rica. Cuadernos de Investigación UNED, 3(1), 89-96.

Tu, A. T. (1976). Investigation of the sea snake, Pelamis platurus (Reptilia, Serpentes, Hydrophiidae), on the Pacific Coast of Costa Rica, Central America. Journal of Herpetology, 10(1), 13-18.

Tu, A. T. (1988). Pharmacology of sea snake venoms. In B. W. Halstead (Ed.), Poisonous and Venomous Marine Animals of the World (pp. 235-258). Princeton: Darwin Press.

Tu, A. T., \& Salafranca, E. S. (1974). Immunological properties and neutralization of sea snake venoms (II). The American Journal of Tropical Medicine and Hygiene, 23(1), 135-138. https://doi.org/10.4269/ ajtmh.1974.23.135

Vallarino, O., \& Weldon, P. J. (1996). Reproduction in the yellow-bellied sea snake (Pelamis platurus) from Panama: Field and laboratory observations. Zoo Biology, 15(3), 309-314. https://doi. org/10.1002/(sici)1098-2361(1996)15:3<309::Aidzoo9>3.0.Co;2-f

Voris, H. K. (1972). The role of sea snakes (Hydrophiidae) in the trophic structure of coastal ocean communities. Journal of the Marine Biological Association of India, 14, 429-442. 